\title{
Design Of The Accounting Course Focusing On The Development Of Competences
}

\author{
Adelaida Ciudad-Gómez, University of Extremadura, Spain
}

\begin{abstract}
The aim of this work is to develop a proposal for a methodology in the university environment that enables us to design our course with an approach based on the development and acquisition of competences within the framework of the European Higher Education Area (EHEA), allowing a transition from a model focused on teaching to a model focused on student learning.

This means, after having established the competences to be acquired by the student during our course, designing the activities that must be undertaken in order to achieve them, so that the central core of our work is made up of three sequential steps: a) selection and definition of the generic and specific competences to be acquired during our course, b) inclusion of competence training activities and distribution amongst the topics of the course, and c) the procedure for the assessment of competences.
\end{abstract}

Keywords: Accounting; Skills Training; Competency Assessment; Higher Education

\section{INTRODUCTION}

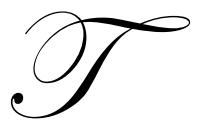

he integration of our Spanish University System into the European Higher Education Area (EHEA), has resulted in a significant change to the model for university education, leading to an approach focused on learning and on competences that has replaced the traditional system that was more focussed on teaching and the acquisition of knowledge.

When conceptually defining the term competence, we find that there is no unique and unambiguous definition; however, despite the existence of several different points of view, there is a consensus that competences represent a dynamic combination of knowledge, skills, capabilities, values and attitudes, and the existence of a connection between the concept of competence and a professional profile and training for performance at work.

In this sense, the Organization for Economic Cooperation and Development (OECD) divides the key competences into three categories: Use tools interactively, interact in heterogeneous groups and act autonomously (OECD, 2005).

The European Union, on the other hand, in its project "Tuning Educational Structures in Europe" (2006: 9 and 90) states that competences represent a dynamic combination of knowledge, understanding, skills and capabilities, differentiating between specific competences (that are specific to the area of study) and generic competences (that are transferable and part of any degree). With regard to the latter, it highlights their growing importance in terms of the preparation of students for employment and social integration, and divides them into three types: instrumental competences, interpersonal competences and systemic competences, and presents a ranking of the generic competences by order of importance, based on a consultation carried out with groups outside the academic world (graduates and employers). 
If we focus on the field of accounting, in recent decades major accounting organizations have reconsidered the guidelines for higher education in accounting. In particular, the American Accounting Association- AAA (1986), the American Institute of Certified Public Accountants-AICPA (1988, 1990, and 1992), the major international accounting firms and auditors (Arthur Andersen \& Co. et al., 1989), the Accounting Education Change CommissionAECC (1990) and the International Federation of Accountants-IFAC (1994 and 1996) all coincide in pointing out that skills, abilities and values in professional conduct are as important as knowledge.

More recently, the International Accounting Education Standards Board (IAESB), a body of the IFAC, in the Framework for International Education Standards for Professional Accountants (IFAC, 2010:13), distinguishes between skills, capabilities and competences, defining skills as part of set of capabilities necessary for accounting professionals to be able to demonstrate their competence in professional performance, dividing them into: (a) professional knowledge, (b) professional skills, (c) professional values, ethics, and attitudes.

On the other hand, AICPA has developed the "Core Competency Framework", a set of required skills that are divided into three categories: functional, personal and broad business perspective competencies, and it is worth highlighting the fact that the competence "Leverage Technology" is included in each of the three areas of expertise, making it particularly important.

\section{DESIGN OF THE FINANCIAL ACCOUNTING III COURSE BASED ON COMPETENCES}

The addition of competences to the teaching / learning process was designed to bring the University closer to society and to the world of work, forcing us to use models that focus on student learning, teaching methods based on competences and procedures that allow us to evaluate these.

The teaching methodology presented in this work has been applied to the subject Financial Accounting III, which is part of the Accounting module of the curriculum for the Degree in Business Administration.

Financial Accounting III is a compulsory course worth 6 ECTS credits, whose purpose or objective is to train students in the formulation, presentation and understanding of Financial Statements, especially those that must be formulated periodically in accordance with national and international accounting rules, i.e. the Annual Accounts and Interim Financial Statements that may be requested by any current or potential user.

\subsection{Selection and definition of the competences to be developed}

When selecting the generic and specific competences to be acquired in Financial Accounting III, it was necessary to coordinate this with the rest of the teachers of the accounting module.

The objectives set include the achievement of certain specific competences related to the formulation, presentation and understanding of Financial Statements and course's design also includes a set of generic competences (mostly pertaining to a basic level of achievement).

However, we considered it appropriate to focus more intensively on the following generic competences: capacity for analysis and synthesis (C01), oral and written communication in your native language (C03), elementary computing skills (C05), ability to analyze and seek information from various sources (C06), problem solving (C07), critical and self-critical abilities (C14) and capacity to learn autonomously (C17), as well as all of the specific competences.

Each of the competences should be broken down into capabilities and, in turn, skills, enabling us to design activities that will be proposed in order to enable students to develop their competences and their subsequent evaluation.

The values and attitudes that we have tried to foster amongst students include honesty, responsibility, discipline, respect and quality; which are essential for the development of competences such as Ethical commitment (C15) and Concern for quality" (C 22).. 
Lastly, the course is organized into eight topics, which includes the study of the formulation, presentation and understanding of Financial Statements.

Table 1. Description of competences to develop in Accounting

\begin{tabular}{|l|}
\hline Instrumental competences \\
\hline C01. Capacity for analysis and synthesis \\
C02. Capacity for organization and planning \\
C03. Oral and written communication in your native language. \\
C05. Elementary computing skills. \\
C06. Ability to analyze and seek information from various sources \\
C07. Problem solving \\
Interpersonal competences \\
\hline C09. Teamwork \\
C12.Interpersonal skills \\
C14. Critical and self-critical abilities \\
C15. Ethical commitment \\
\hline Systemic competences \\
\hline C17. capacity to learn autonomously \\
C22. Concern for quality \\
C23. Sensitivity to environmental and social issues \\
\hline Specific competences \\
\hline C29. Know the process of communication of external information in the business. \\
C35. Knowing the process of closing the accounting cycle and preparing the information necessary for the preparation of \\
financial statements, paying particular attention to mandatory required by law. \\
C48. Capacity for applying knowledge in practice \\
C51. Capacity for the dissemination of economic issues \\
C53. Apply knowledge to their work and solving problems within their area of study. \\
C55. Transmit information, ideas, problems and solutions. \\
S0ure Curions
\end{tabular}

Source: Curriculum of Business Administration and Management

\subsection{Inclusion and distribution of activities}

Once the content of the course has been established, taking into account the competences and the subject concerned, it is necessary to decide on the teaching methods or techniques during the design of the teaching strategy stage, in order to prepare for the execution or implementation of teaching activities.

Given this teaching context and our desire to improve, we decided to incorporate new technologies into our teaching-learning process and we proposed the creation of the virtual course using the Moodle platform, which makes it possible to combine distance learning with classroom learning.

Our goal in using the Moodle e-learning platform was to obtain a tool that allows us to develop a learning process that is controlled and directed by the teacher, to increase student participation, and to train and evaluate students not only in the specific competences of our discipline but also generic competences, to increase their knowledge of new information technologies (ICT) and provide them autonomy.

For this purpose, both material and activities related to training and assessment in competences are included in an organized manner on the Moodle platform (Ciudad, 2010).

Amongst the online activities, students have been provided self-assessment tests which are added as "questionnaires" and "tasks" e.g. "Advanced file upload" for the resolution of eminently practical situations which require the use of software.

These activities are aimed at developing the students' ability to apply knowledge in practical situations (C48), computer skills related to the area of study (C05) and problem solving abilities (C07), as well as the development of specific competences. 
"Virtual forums" have also been used to propose discussions about specific topics. In the first subjects we provided the material to be analyzed and then the students themselves were required to look for information on the Internet and in other bibliographic sources for subsequent analysis and synthesis.

Student were asked, after having analyzed and summarized the documentation used, to submit their summaries through the forum and then to give their opinions on the contributions of their peers.

The aim of this activity is to develop and assess competences such as the capacity for analysis and synthesis (C01), written communication in native language (C03), ability to analyze and seek information from various sources (C06), critical and self-critical abilities (C14) and the capacity for autonomous learning (C17).

Apart from being useful as a training tool, the virtual forum is also useful as an assessment tool, as Moodle provides detailed information about the interventions of each student and allows us to assess the number of times they have participated, the size of their interventions, content, type of communication, etc.

With regard to classroom activities, students are asked to solve practical problems, an activity that is particularly related to the following competences: problem solving $(\mathrm{C} 07)$ and the ability to put knowledge into practice (C48), although this also helps to develop generic competences such as oral and written communication (C03), computer skills related to the area of study (C05), and critical and self-critical abilities (C14), or competences specific to the subject.

Students may also carry out and present work related to the course's content or make comments on articles, presenting them appropriately in public. This activity is useful for acquiring generic competences such as: the capacity for analysis and synthesis (C01), the capacity for organisation and planning (C02), oral and written communication (C03), IT knowledge related to the area of study (C05), ability to analyze and seek information from various sources (C06), and the capacity for autonomous learning (C17), as well as the capacity to work in a team (C09) if it is carried out in groups. Activities that have been distributed throughout the course as shown in table 2.

Table 2. Classroom and online activities.

\begin{tabular}{|c|c|c|c|}
\hline Items Or Content & Online Activities & \multicolumn{2}{|c|}{ Classroom Activities } \\
\hline The Communication Of Accounting Information & Questionnaire & - & \multirow{8}{*}{$\begin{array}{l}\text { Carry out } \\
\text { and publicly } \\
\text { present } \\
\text { works or } \\
\text { comments } \\
\text { on articles }\end{array}$} \\
\hline Balance Sheet & \multirow{2}{*}{ Tasks } & \multirow{5}{*}{$\begin{array}{l}\text { Resolution of } \\
\text { practical cases, } \\
\text { applying } \\
\text { theoretical } \\
\text { knowledge. }\end{array}$} & \\
\hline Statement Of Income & & & \\
\hline Statement Of Owners`Equity & Forum / Debate: XBRL & & \\
\hline Statement Of Cash Flows & Forum / Debate: USALI & & \\
\hline Notes To The Financial Statements & Questionnaire & & \\
\hline Other Information & Tasks & - & \\
\hline Information Social And Environmental & Forum / Debate & - & \\
\hline
\end{tabular}

Furthermore, all of the activities mentioned above help to develop the students' proficiency in computer management and ICT, as they have to submit work and assignments using software applications and they have to submit the information required found using internet search engines, which may be used as evidence of the achievement of this competence.

Lastly, to promote values and attitudes amongst the students such as honesty, responsibility, discipline, respect and quality, certain guidelines for behaviour in the subject have been established: being punctual, meeting deadlines, not blaming other people for their actions, not cheating with work, assignments, or exams, avoiding involvement in dishonest academic behaviour, respecting the opinions and work of others, cleanliness, tidiness, etc.

\subsection{Procedures for the evaluation of the competences}

With the focus on competences it is not enough to just assess the knowledge acquired by the student, as has been done in the past. Furthermore, the objective of the evaluation should not be limited to control, but also training 
and motivation as, as has been noted by González (2006), one of the requirements for training and the development of competences at the University is that evaluation is conceived in its formative dimension.

Therefore, the evaluation process that we propose, derived from the teaching method applied, is a continuous assessment throughout the course, together with the results of the officially announced exams, applying a weighted average of all the activities carried out by the students.

This evaluation model is intended, on the one hand, to serve as a methodological tool to support the teaching \& learning process (assessment as learning) and, on the other hand, to enable us to document the evidence of the process and the result of acquisition of competences by the students (assessment of learning).

However, when carrying out our formative evaluation, we had great difficulty in assessing the performance focused on qualitative aspects and therefore we think that in the future it would be useful to use headings, a tool that will enable us to more easily assess the performance focused on qualitative aspects and that will also provide students with information about what to do to achieve the necessary competencies.

For this purpose, a heading shall be designed for each activity, defining the criteria (aspects to be evaluated) and the indicators or descriptors (levels of performance of the criteria) and, once designed, it shall be tested, evaluated and adjusted.

These headings shall be presented to students so that they are clear about both the criteria and their different levels, ensuring that students clearly understand how they are being assessed and what each level represents with regard to the points assigned.

Furthermore, as the generic competences are developed and assessed in different subjects, all of information from the headings can be exported to a record sheet that provides information about the stage reached in the competences and informs teachers about the next learning stage (assessment for learning).

With regard to values and attitudes, the methodology applied is assessment through observation, which allows us to take into account the students' attitude and the effort made.

\section{CONCLUSIONS}

In the EHEA's approach based on competences, competencies are considered essential for the successful professional performance of our students in environments that are subject to continuous changes, highly demanding and competitive, in which skills, abilities and values in professional conduct are as important as the acquisition of knowledge.

All of this has made it necessary to rethink and improve our teaching / learning methodology and the assessment procedures used - is not enough to simply evaluate the knowledge acquired by the student; we must also assess their skills using an evaluation model that is closely related to the content and methodology applied.

In this respect, one of the requirements for the training and development of competences is to conceive the assessment of learning as a formative concept, but we believe that we must go further and try to ensure that the methodology we apply in the evaluation process is the assessment of learning, assessment as learning and assessment for learning, which provides information to those responsible for the next stages of the teaching / learning process.

When developing our training program based on the development of competences, decisions about the teaching methods adopted have been based on the need to provide assistance and guidance to students in order to enable them to achieve the level of development required in each of the competences.

The teaching methodology proposed in this work has been designed for the subject "Financial Accounting III" of the Degree in Business Administration course, in which generic and specific competences are developed. For 
this purpose, we have designed a model combining different strategies and instruments that makes it possible to document evidence of knowledge and performance and that also serves as a methodological tool supporting the teaching / learning process.

In order to provide the necessary support to students we have used the Moodle platform, which has also enabled us to also provide students knowledge of and experience with new Information Technologies (ICTs).

Our methodology, based on active student participation, has been implemented through online and classroom activities that enable the development and evaluation of knowledge as well as skills and values. However, during the implementation of our formative evaluation, we have encountered two major difficulties: one due to there being more than 100 students and the other due to the need to evaluate performance based on qualitative aspects.

With regard to the latter limitation, we think that it could be useful in the future to use headings, a tool that would enable us to more easily assess performance based on qualitative aspects, and which would provide students with information on what to do in order to achieve the necessary competences and would inform teachers of the next learning stage about the level achieved in the competences, by means of a record sheet drawn up based on the information from the headings.

Finally, with our methodological approach we have taken the first step in making our evaluation model useful for the development and evaluation of competences, but this must be improved in order to achieve continuous improvement in the quality of our teaching. Therefore, we have given it a certain amount of flexibility in order to enable us to make any necessary changes.

\section{AUTHOR INFORMATION}

Adelaida Ciudad-Gomez, Degree in Business Administration by University of Sevilla. Associate Professor at Accounting and Finance Department. Faculty of Business Studies and Tourism of Cáceres. University of Extremadura (Spain). E-mail: adelaida@unex.es.

Research Interest: Accounting, educational, tourism and environment.

\section{REFERENCES}

1. Accounting education change commission- AECC (1990). Position statement number one: Objectives of education for accountants. Available in: http://aaahq.org/aecc/PositionsandIssues/pos1.htm [accessed 1 mayo 2011].

2. American accounting association-AAA (1986). Future Accounting Education: Preparing for the Expanding Profession (The Bedford Report). En Bloom, R. et al (1994). The Schism in Accounting. Ed. Quorum Books, 89-116.

3. American institute of certified public accountants, Education Executive Committee. (1988): Education Requirements for Entry Into the Accounting Profession (Committee Albers). NY: AICPA.

4. American institute of certified public accountants, Education Executive Committee. (1990): "Accounting Education: An AICPA Position Statement". NY: AICPA

5. American institute of certified public accountants, Education Executive Committee. (1992): "Academic Preparation to Become a Certified Public Accountant". NY: AICPA

6. American institute of certified public accountants (2005): "Core Competency Framework" Available in: http://www.aicpa.org/InterestAreas/AccountingEducation/Resources/CurriculumDevelopment/CoreCompet encyFrameworkandEducationalCompetencyAssessmentWebSite/Pages/default.aspx [accessed 1 April 2011]

7. Arthur Andersen \& Co; Ernst \& Whinney; Arthur Young; Peat Marwick Main \& Co.; Coopers \& Lybrand; Price Waterhouse; Deloitte Haskins \& Sells Y Touche Ross (1989): Perspectives on education: capabilities for success in the accounting profession. Available in: http://aaahq.org/AECC/big8/cover.htm [1 April 2011]. 
8. Ciudad, A. (2010): "Teaching Innovation And Use Of The ICT In The Teaching-Learning Process Within The New Framework Of The EHEA, By Means Of Moodle Platform". American Journal of Business Education (AJBE), Vol 3, No 13.

9. González, V. (2006): "La formación de competencias profesionales en la universidad. Reflexiones y experiencias desde una perspectiva educativa". XXI. Revista de educación, № 8, 175-188.

10. International federation of accountants- ifac. International accounting education standards board-IAESB (2007): Internal Education Practice Statement 2: Information technology for professional accountants Available in: http://www.ifac.org/ Members/DownLoads/IEPS_2_IT_for-Professional_Accountants.pdf [accessed 18 December 2010].

11. International federation of accountants-IFAC. Education Committee. (1994): 2000 and Beyond. A strategic framework for prequalification education for the accountancy profession in the year 2000 and beyond. N.Y., IFAC.

12. International federation of accountants-IFAC. Education Committee. (1996): Prequalification Education, Assessment of professional competence and experience requirements of professional accountants. N.Y., IFAC.

13. International federation of accountants. International accounting education standards board- IAESB (2010). Handbook of international education pronouncements. 2010 edition. Available in: http://web.ifac.org/publications/international-accounting-education-standards-board [accessed 1 April $2011]$.

14. OCDE (2005): "The definition and selection of key competencies (DeSeCo). Executive Summary". Available in: http://www.oecd.org/dataoecd/47/61/35070367.pdf [1 April 2011].

15. TUNING. (2006): "Introduction to Tuning Educational Structures in Europe". Available in: http://tuning.unideusto.org/tuningeu/images/stories/template/General_Brochure_final_version.pdf [accessed 24 April 2011]. 
NOTES 